\title{
建物市場を考慮した 応用都市経済モデルの可能性
}

\author{
堤 盛人 ${ }^{1} \cdot$ 宮城 卓也 $^{2} \cdot$ 山崎 清 $^{3}$ \\ 1正会員 筑波大学准教授システム情報系（†305-8573 茨城県つくば市天王台 1-1-1） \\ E-mail: tsutsumi@sk.tsukuba.ac.jp \\ 2非会員 大成建設株式会社 管理本部（干163-0606 東京都新宿区西新宿 1-25-1） \\ E-mail: mygtky00@pub.taisei.co.jp \\ 3正会員 株式会社価值総合研究所 経済社会政策グループ（†100-0004 東京都千代田区大手町 2-2-1） \\ E-mail: kiyoshi_yamasaki@vmi.co.jp
}

我が国で発展した応用都市経済モデル（CUEM）は，立地者と地主という主体間の土地市場均衡を扱う構 造が一般的である。一方, 海外の土地利用・交通相互作用モデルは, さらに開発者という主体を考慮し, 土 地市場と建物市場を同時に扱う。我が国では土地と建物が個別に取引されていることから，CUEMにおい て土地市場と建物市場を両方明示的にモデル化することでより現実的なシミュレーションが可能になると 考えられる。しかしながら，我が国では建物についてのデー夕取得が困難であったため，建物市場を考慮 したCUEMの実証は少なく, 建物市場の考慮がモデル全体に与える影響を調べた研究は皆無である。本研 究では, 開発者の考慮の有無が分析結果に与える影響を考察することで, 開発者を考慮したCUEMの可能 性について議論する。

Key Words: computable urban economic model, building market, developer, land-use transport interaction model, equilibrium

\section{1. はじめに}

都市・地域における様々な施策・政策評価を行う ために，我が国では，応用都市経済モデル (Computable Urban Economic Model : 以下, CUEM) が 開発されてきた（例えば上田他（2008） $\left.{ }^{1)}\right)$.

CUEM は，静学の経済均衡モデルという形を取り ながら土地利用と交通の相互作用を明示的に考慮し ている点が特徵的であり, 特にいわゆる交通モデル を具備している点が, 一般均衡体系として開発され た土地利用モデルである Anas and Liu (2007） 2) と大 きく異なるところである。

Anas and Liu (2007） 2)のように一般均衡体系で土 地利用モデルを構築する際には，財の取引市場を導 入する必要があり，そのような空間的な財・サービ スの取引を導入するためには財・サービスの移動 (輸 送）を明示的に扱う必要がある。財・サービスの輸 送を明示的に扱うためには, SCGEのようにゾーン 間の輸送費を生産者価格に加えた購入者価格の導入 が必要となる。典型的な方法として, RAEM-Light
(例えば Koike etal. (2009) ${ }^{3)}$ ) や文 (2001） ${ }^{4)}$ のよう に企業から家計に販売する交易量を用いることが考 えられるが, そこでは財・サービスを輸送している 人・物は明示的に区別されていない.

一方, CUEMで焦点を当てている移動（輸送）は, 旅客では移動目的（通勤・私事・業務等）別人トリッ プ, 貨物では車種 (小型貨物, 普通貨物) 別台トリッ プ等の ODトリップである。これらの ODトリップ は, CUEM では伝統的な 4 段階推計法の第 2 段階の 目的地選択モデルとして定式化されており, その際, 財・サービスの輸送は明示されていない。例えば, 私事トリップの場合, 家計が財を消費するのは, 企 業が家計まで実際に物を運んでくるのか, それとも 家計が企業まで物を買いに行くのか, モデルの中で は区別して考えられていない.

現在の我が国で一般的に利用可能な統計デー夕に おいて, 財・サービスの輸送とそれを輸送する人・物 を同時に明示的に区別することは困難である。都 市・地域といった空間スケールを対象として施策・ 政策の評価を行う上では，財・サービスの輸送を明 


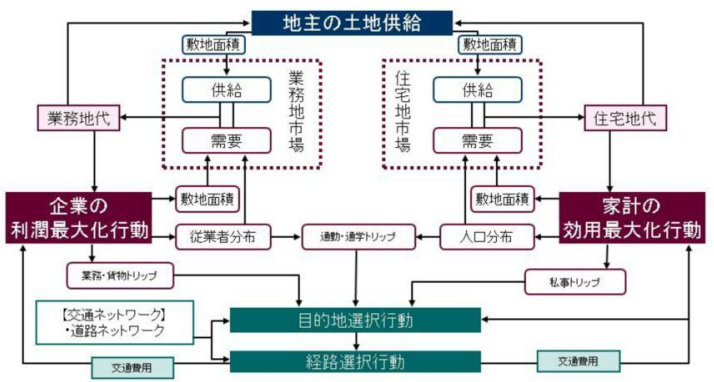

図-1 従来型 CUEM の全体構成

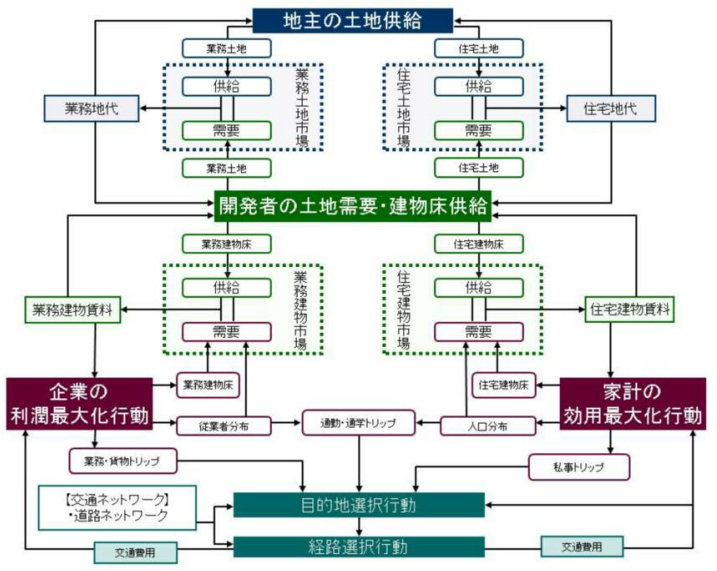

図-2 新型 CUEM の全体構成
示的には扱わない代わりに，既存の CUEMのように 部分均衡体系としてのモデル化することで，パーソ ントリップ調査等の統計データとの整合性を確保す ることの利点は大きいと考えられる.

ところで，従来の CUEM では，立地者と地主とい う主体間の土地市場均衡を扱うのが一般的である が，土地市場に加えて建物市場を考慮することに よって, 容積率規制等の政策シミュレーションや建 物からの $\mathrm{CO}_{2}$ 排出量を推計する際に必要となる建物 床面積の将来予測が可能になるなど，これまで以上 に多様な都市政策を議論するための有効な分析ツー ルに成り得る。実際，海外の土地利用モデル（例え ば，Anas and Liu (2007） 2)，Waddell (2002） ${ }^{5)}$ ) で は, 開発者という主体を考慮し, 建物市場均衡と土 地市場均衡を同時に扱う構造となっている。

そもそも，我が国では土地と建物が個別に取引さ れることが多く，CUEMにおいて土地市場と建物市 場を両方明示的に考慮することは現実のモデル化と いう意味においても自然である.

しかしながら，我が国では建物賃料や建物床面積 についてのデータ取得が容易でなかったことなどか ら, 建物市場を考慮した CUEM (以下,「新型 CUEM」 と略記）に関する研究は，筆者らが知る限り, Ueda et al. (1993) 6) , 平谷他 (1993) 7)のみである。そ己で は, 当時, 建物床面積に関するデータが利用可能で あった広島市を分析対象地域として 新型 CUEM を 構築しているが, 同一の分析対象地域で建物市場を 明示的に考慮しない場合との比較を行っておらず, 建物市場の考慮がモデル分析の結果に与える影響に ついて考察されていない.

そこで, 本研究では, 建物市場の考慮の有無が分 析結果に与える影響を実証的に考察するために，土 地市場のみを扱う CUEM（「従来型 CUEM」と略記） と新型 CUEM を比較可能な形で構築し, 両者を同一
の分析対象に適用しその結果を考察するとともに, 新型 CUEM の実用可能性について議論する.

本研究では, 従来型 CUEM として, 上田 $(1991)^{8)}$, 上田 $(1992)^{9)}$, 武藤他 $(2000)^{10)}$ 等によって構築さ れた枠組みを基本的に踏襲しながら東京都市圈に適 用するために改良された，千葉県・株式会社価值総 合研究所 (2007) 11) において開発されたモデル（貨

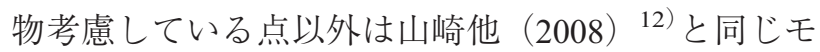
デル）を用いる。モデルの全体構成は図-1に示す通 りである。

\section{2. 建物市場を考慮した応用都市経済モデル}

\section{（1）モデルの全体構成}

本研究では，千葉県・株式会社価值総合研究所 （2007） ${ }^{11)}$ のモデルに建物市場を組み込むことで，新 型 CUEM を構築した。建物市場を組み込む上で新 たに考えるべき主体である「開発者」は, 建物市場に おいて家計・企業と建物床の賃貸取引を行う。また, 土地市場において地主と土地の賃貸取引を行う。モ デルの全体構成は図-2に示す通りであり，前提条件 は以下の通りである。

1）経済主体としては，同一の選好を持つ人口 1 人 当たりで捉えた家計，職業・産業別の区分の無い従 業者 1 人当たりで捉えた企業, 地主, そして, 開発者 を考える。

2）都市圈内は $i$ 個のゾーンに分割されており，各 ゾーンにおける同一用途内は均質である.

3）都市圏（対象地域）の総人口，総従業者数は外 生的に与えられ，都市圈外との交流は無いと仮定す る(いわゆる閉鎖都市モデル).

4) 家計は効用最大化, 企業は利潤最大化に従って, それぞれ立地選択行動を行うものとし，立地の変化 
による追加的な費用は一切考慮しない。開発者, 地 主も利潤最大化行動に従う。

\section{（2）モデルの定式化 \\ a) 家計の行動}

代表的一人の家計を仮定し, 家計は所得制約の下 で，自身の効用を最大化するように住宅建物床面積， 私事トリップ, 合成財を消費し，その結果として得 られる効用值に基づき居住地選択を行う。土地消費 に代わって建物床消費を考える点が従来型 CUEM と異なる。

家計の消費行動は式 (1.a), (1.b) のように定式化 し, 効用関数は住宅建物床面積, 私事トリップ消費, 合成財を財として対数線形で特定化する.

$$
\begin{aligned}
& V_{i}^{H}=\max _{z_{i}^{H}, A_{i}^{H}, x_{i}^{H}}\left[\alpha_{z} \ln z_{i}^{H}+\alpha_{a} \ln A_{i}^{H}+\alpha_{x} \ln x_{i}^{H}\right] \\
& \text { s.t. } \quad z_{i}^{H}+R_{i}^{H} A_{i}^{H}+q_{i}^{H} x_{i}^{H}=w\left(T-q_{i}^{w} x_{i}^{w}\right)
\end{aligned}
$$

$V_{i}^{H}$ : ゾーン $i$ の世帯の効用水準, $z_{i}^{H}$ : 価格を 1 と した合成財の消費量 (=支出額), $A_{i}^{H}$ : 住宅建物床面 積消費量, $x_{i}^{H}$ : 私事トリップ消費量, $\alpha_{z}, \alpha_{a}, \alpha_{x}$ : 分配パ ラメータ, $R_{i}^{H}$ : ゾーン $i$ の住宅建物賃料, $q_{i}^{H}$ : 私事卜 リップの一般化価格, $w$ : 賃金率, $T$ : 総利用可能時 間 (固定), $q_{i}^{w}$ : 通勤トリップの一般化価格, $x_{i}^{w}:$ 通 勤トリップ消費量

式（1）を解くと，各財の消費量が求められる.

$$
\begin{gathered}
z_{i}^{H}=\alpha_{z} I_{i} \\
A_{i}^{H}=\frac{\alpha_{a}}{R_{i}^{H}} I_{i} \\
x_{i}^{H}=\frac{\alpha_{x}}{q_{i}^{H}} I_{i} \\
I_{i}=w\left(T-q_{i}^{w} x_{i}^{w}\right)
\end{gathered}
$$

ただし, $\alpha_{z}+\alpha_{a}+\alpha_{x}=1 \quad$ (2. e)

式（2）を式（1）に代入し, 間接効用関数が導出さ れる。

$$
\begin{gathered}
V_{i}^{H}=\ln I_{i}-\alpha_{a} \ln R_{i}^{H}-\alpha_{x} \ln q_{i}^{H} \\
+\alpha_{z} \ln \alpha_{z}+\alpha_{a} \ln \alpha_{a}+\alpha_{x} \ln \alpha_{x}
\end{gathered}
$$

式（3）から導かれる間接効用関数及び住環境や地 形的要因などの地域固有の指標 $\left(e_{i}^{H}\right)$ から構成され る「立地魅力度 $\left(v_{i}^{H}\right) 」$ に基づき, 宮城・小川 (1985) ${ }^{13)}$ により定義された「選択の基本公式」に従い行動す る。

$$
\begin{gathered}
S^{H}=\max _{p_{i}^{H}}\left[\sum_{i} P_{i}^{H}\left(v_{i}^{H}\right)-\frac{1}{\theta^{H}} \sum_{i} P_{i}^{H} \ln \left(P_{i}^{H}\right)\right] \\
\text { s.t. } \quad \sum_{i} P_{i}^{H}=1 \\
v_{i}^{H}=V_{i}^{H}+e_{i}^{H}
\end{gathered}
$$

式（4）を解くことにより，以下のような立地選択 確率及び期待最大効用が導出される.

$$
\begin{gathered}
P_{i}^{H}=\frac{\exp \left(\theta^{H} v_{i}^{H}\right)}{\sum_{i^{\prime}} \exp \left(\theta^{H} v_{i}^{H}\right)} \\
S^{H}=\frac{1}{\theta^{H}} \ln \left[\sum_{i} \exp \left(\theta^{H} v_{i}^{H}\right)\right]
\end{gathered}
$$

ここで各ゾーンの集計された住宅建物床面積と私 事トリップ数の需要関数を導出する. 具体的には, 家計 1 人あたりの需要関数である式 (2.b), (2. c) に, 各ゾーン人口を乗じる. ゾーン人口は都市圈総 人口 $\left(N^{T}\right)$ に式 $(5)$ の立地選択確率を乗じた量とな る.

$$
\begin{aligned}
& Z A_{i}^{H}=A_{i}^{H} N^{T} P_{i}^{H} \\
& Z X_{i}^{H}=x_{i}^{H} N^{T} P_{i}^{H}
\end{aligned}
$$

$Z A_{i}^{H}:$ ゾーン住宅建物床需要量, $Z X_{i}^{H}:$ ゾーン発 生私事トリップ数

\section{b）企業の行動}

企業の利潤最大化行動は業務建物床面積と業務卜 リップ，貨物トリップを投入して，生産技術制約の 下で利潤が最大となるように生産を行っているもの とし，生産関数をコブ・ダグラス型技術により特定 化する，家計の行動と同様に，土地消費に代わって 建物床消費を考える点が従来型 CUEM と異なる.

$$
\begin{gathered}
\prod_{i}^{B}=\max _{a_{i}^{B}, x_{i}^{B}, x_{i}^{F}}\left[Z_{i}^{B}-R_{i}^{B} A_{i}^{B}-q_{i}^{B} x_{i}^{B}-q_{i}^{F} x_{i}^{F}\right] \\
\text { s.t. } Z_{i}^{B}=\eta_{i}\left(A_{i}^{B}\right)^{\beta a}\left(x_{i}^{B}\right)^{\beta b}\left(x_{i}^{F}\right)^{\beta f}
\end{gathered}
$$

$Z_{i}^{B}$ : 合成財生産量, $R_{i}^{B}$ : 業務建物賃料 (単位面積当 たり), $A_{i}^{B}$ : 業務建物床投入量, $q_{i}^{B}$ : 業務トリップ一 般化価格, $x_{i}^{B}$ : 業務トリップ投入量, $q_{i}^{F}$ : 貨物トリッ プ一般化価格, $x_{i}^{F}$ : 貨物トリップ投入量, $\eta_{i}$ : 生産効 率パラメー夕, $\beta_{a}, \beta_{b}, \beta_{f}:$ 分配パラメー夕

式（7）を解くことにより，企業の生産要素需要で ある業務建物床投入量 $\left(A_{i}^{B}\right)$, 業務卜リップ $\left(x_{i}^{B}\right)$, 貨物トリップ $\left(x_{i}^{F}\right)$ が以下のように求められる. 


$$
\begin{aligned}
& A_{i}^{B}=\left\{\frac{1}{\eta_{i}}\left(\frac{R_{i}^{B}}{\beta_{a}}\right)^{1-\beta_{b}-\beta_{f}}\left(\frac{\beta_{b}}{q_{i}^{B}}\right)^{-\beta_{b}}\left(\frac{\beta_{f}}{q_{i}^{F}}\right)^{-\beta_{f}}\right\}^{\frac{1}{\beta_{a}+\beta_{b}+\beta_{f}-1}} \\
& x_{i}^{B}=\left\{\frac{1}{\eta_{i}}\left(\frac{q_{i}^{B}}{\beta_{b}}\right)^{1-\beta_{a}-\beta_{f}}\left(\frac{\beta_{a}}{R_{i}^{B}}\right)^{-\beta_{a}}\left(\frac{\beta_{f}}{q_{i}^{F}}\right)^{-\beta_{f}}\right\}^{\frac{1}{\beta_{a}+\beta_{b}+\beta_{f}-1}} \\
& x_{i}^{F}=\left\{\frac{1}{\eta_{i}}\left(\frac{q_{i}^{F}}{\beta_{f}}\right)^{1-\beta_{a}-\beta_{b}}\left(\frac{\beta_{a}}{R_{i}^{B}}\right)^{-\beta_{a}}\left(\frac{\beta_{b}}{q_{i}^{B}}\right)^{-\beta_{b}}\right\}^{\frac{1}{\beta_{a}+\beta_{b}+\beta_{f}-1}}
\end{aligned}
$$

式（8）を生産関数に代入すると, 生産物の供給が 式（9）のように求められる。また式（9）を用いて利 潤が式（10）のように導出される.

$$
\begin{gathered}
Z_{i}^{B}=\left\{\frac{1}{\eta_{i}}\left(\frac{R_{i}^{B}}{\beta_{a}}\right)^{\beta_{a}}\left(\frac{q_{i}^{B}}{\beta_{b}}\right)^{\beta_{b}}\left(\frac{q_{i}^{F}}{\beta_{f}}\right)^{\beta_{f}}\right\}^{\frac{1}{\beta_{a}+\beta_{b}+\beta_{f}-1}} \\
\prod_{i}^{B}=\left(1-\beta_{a}-\beta_{b}-\beta_{f}\right)\left\{\frac{1}{\eta_{i}}\left(\frac{R_{i}^{B}}{\beta_{a}}\right)^{\beta_{a}}\left(\frac{q_{i}^{B}}{\beta_{b}}\right)^{\beta_{b}}\left(\frac{q_{i}^{F}}{\beta_{f}}\right)^{\beta_{f}}\right\}^{\frac{1}{\beta_{a}+\beta_{b}+\beta_{f}-1}}
\end{gathered}
$$

企業の立地選択行動は世帯の居住者選択行動と基 本的には同様に, 利潤関数 $\left(\Pi_{i}^{B}\right)$ と業務環境や地形 的要因等の地域固有の指標 $\left(e_{i}^{B}\right)$ から構成される「立 地魅力度 $\left(\pi_{i}^{B}\right) 」$ に基づき立地選択行動を行う.

$$
\begin{gathered}
S^{B}=\max _{p_{i}^{B}}\left[\sum_{i} P_{i}^{B}\left(\pi_{i}^{B}\right)-\frac{1}{\theta^{B}} \sum_{i} P_{i}^{B} \ln \left(P_{i}^{B}\right)\right] \\
\text { s.t. } \quad \sum_{i} P_{i}^{B}=1 \\
\pi_{i}^{B}=\prod_{i}^{B}+e_{i}^{B}
\end{gathered}
$$

式（11）を解くことにより，以下のような立地選択 確率及び期待最大利潤が導出される.

$$
\begin{gathered}
P_{i}^{B}=\frac{\exp \left(\theta^{B} \pi_{i}^{B}\right)}{\sum_{i^{\prime}} \exp \left(\theta^{B} \pi_{i}^{B}\right)} \\
S^{B}=\frac{1}{\theta^{B}} \ln \left[\sum_{i} \exp \left(\theta^{B} \pi_{i}^{B}\right)\right]
\end{gathered}
$$

ここで各ゾーンの集計された業務建物床需要量と 業務トリップ数, 貨物トリップ数の需要関数を導出 する。すなわち，1企業あたりの需要関数である式 (8.a)，（8.b)，（8.c ）に，各ゾーン従業者数を乗じ る。ゾーン別従業者は都市圈総従業者 $\left(E^{T}\right)$ に式 (12.a) の立地選択確率を乗じた量となる.

$$
\begin{aligned}
& Z A_{i}^{B}=A_{i}^{B} E^{T} P_{i}^{B} \\
& Z X_{i}^{B}=x_{i}^{B} E^{T} P_{i}^{B} \\
& Z X_{i}^{F}=x_{i}^{F} E^{T} P_{i}^{B}
\end{aligned}
$$

$Z A_{i}^{B}:$ ゾーン業務建物床需要量, $Z X_{i}^{B}$ : ゾーン発生 業務トリップ数, $Z X_{i}^{F}$ : ゾーン発生貨物トリップ数
土木学会論文集D3 (土木計画学), Vol. 68, No. 4, 333-343, 2012.

\section{c）開発者の行動}

本研究では Ueda etal. (1993) ${ }^{6)}$, 平谷他 (1993) ${ }^{7)}$ と同様に開発者の静学的行動モデルを構築した，具 体的には，開発者は各ゾーンの住宅・業務の用途別 に 1 人ずつ存在すると仮定し，建物市場において立 地者とそれぞれ取引を行う。資本と土地を生産要素 財とし，容積率規制内で建物生産による利潤を最大 にすると仮定する，建物の除去，耐久性，最適開発 時点等の動学的要素は考慮していない.

$$
\prod_{i}^{D}=\max _{Q_{i}, L_{i}, K_{i}}\left[R_{i} Q_{i}-P_{i} L_{i}-M K_{i}\right]
$$

$$
Q_{i}=\nu \cdot L_{i}^{a} \cdot K_{i}^{b}
$$

$\Pi_{i}^{D}:$ ゾーン $i$ の開発者の利潤, $R_{i}$ : 建物賃料, $Q_{i}$ : 建物生産床面積, $P_{i}$ : 土地地代, $L_{i}$ : 開発者に供給さ れた土地面積, $M$ :土地以外の資材価格 (一定), $K_{i}$ : 土地以外の資材投入量, $a, b, \nu$ : パラメー夕（但し, $0<a+b<1)$

式 (14) の最適化問題を解くと, 利潤関数は式 (15) のようになる。これに Hotteling の補題を用いること で, 建物床供給関数 $\left(Q_{i}\right)$ と土地需要関数 $\left(L_{i}\right)$ が式 (16)，（17）のと扔り導出される.

$$
\Pi_{i}^{D}=\varphi_{1} \cdot R_{i 1-a-b}^{\frac{1}{1-a-b}}
$$

$$
Q_{i}=\varphi_{2} \cdot R_{i 1-a-b}^{a+b} \cdot P_{i}-\frac{a}{1-a-b}
$$

$$
L_{i}=\varphi_{3} \cdot R_{i 1-a-b}^{\frac{1}{1-a-b}} \cdot P_{i}-\frac{1-b}{1-a-b}
$$

$\varphi_{1}, \varphi_{2}, \varphi_{3}$ : パラメータ (平谷他 $(1993)^{7)}$ 参照)

但し， $Q_{i}$ が法定容積率による制限を超える場合, 開発者の建物床供給関数, 土地需要関数は式（18）, （19）になる.

$$
\begin{gathered}
Q_{i}=\bar{Q}_{i} \\
L_{i}=\bar{Q}_{i} / \mu_{i}
\end{gathered}
$$

$\bar{Q}_{i}$ : 法定容積率から算出される限界可能建築建物 床面積, $\mu_{i}$ : 法定容積率

\section{d）地主の行動}

地主は各ゾーンの住宅，業務用途の土地に 1 人ず つ存在すると仮定し，土地供給は需要者である開発 者に対し利用可能な土地を用途別 (住宅, 業務) に提 供すると仮定する。

$$
y_{i}=\left(1-\frac{\sigma_{i}}{P_{i}}\right) Y_{i}^{O}
$$


$y_{i}$ : 土地供給量, $Y_{i}^{o}$ : 利用可能面積, $\sigma_{i}:$ パラメータ

ここで土地の利用可能面積は都市計画区域等の土 地利用計画における最大供給量であり，本モデルで はこれを外生変数として扱うが, 土地供給量は内生 変数であり, 地代に応じて地主が戦略的にコント ロール可能な変数である。そそのため地代の低下によ り土地供給量が減少する場合もあるが，現実的には 土地は宅地として一度供給された場合には恒久的に 宅地として利用されることが一般的であり, 宅地が 減少していくことは考え難い，そのため，ここでの 地代の低下による土地面積の減少は宅地供給された 後の駐車場等の遊休地等の可能性を想定したもので あると解釈するのが適切である.

なお，式（20）の供給関数は，千葉県・株式会社価 值総合研究所 (2007) ${ }^{11)}$ において利潤最大化行動か ら導かれたものである。費用関数の設定にやや $a d$ hoc な面も残されているが, 本研究では, 従来型 CUEM との比較を主眼に置くため, これを踏襲する こととする.

\section{e）清算条件}

新型 CUEM では立地均衡, 土地市場均衡, 建物市 場均衡を考える。

立地均衡とは，もはやどの主体も自らの立地選択 確率を変更しても各主体の目的関数の水準を向上さ せることはできない，いわゆるパレート最適の状態 であり，立地数の清算条件は式 (21.a) (21. b) のよ うに各ゾーンの立地需要量の総和が都市圈の総立地 者数と合致することである。

$$
\begin{aligned}
& \sum_{i} N_{i}=N^{T} \\
& \sum_{i} E_{i}=E^{T}
\end{aligned}
$$

新型 CUEM で考える財は建物，土地である，建 物, 土地は典型的な移動不可能財, しかも消費され る頻度が高いことから日常的な財であると考えられ る。このような財の性質から, 地域を越えて需要, 供給されることはなく，市場は地域内で排他的に形 成される，従って市場均衡条件は以下のように表現 される。

建物市場の清算条件は各ゾーンに扔ける家計，企 業の建物床需要量 (式 (6.a), (13.a)) と各ゾーンの 開発者の供給する建物床面積（式（16）もしくは式 (18））が合致することである.

$$
Z A_{i}^{H}=Q_{i}^{H}
$$

$$
Z A_{i}^{B}=Q_{i}^{B}
$$

$H$ : 住宅用途， $B$ : 業務用途（用途別に算出）

土地市場の清算条件は各ゾーンに打ける開発者の 土地面積需要量（式 (17) もしくは式 (19)) と各ゾー ンの地主の土地面積供給量 (式 (20)) が合致するこ とである。

$$
\begin{aligned}
& L_{i}^{H}=y_{i}^{H} \\
& L_{i}^{B}=y_{i}^{B}
\end{aligned}
$$

\section{f）交通モデル}

交通行動は家計及び企業からの発生交通の下で, 目的地，経路を決定するものである.

発生交通は効用最大化及び利潤最大化行動によっ て求められた家計の私事トリップ消費量 (式 (6.b)), 企業の業務トリップ消費量 (式 (13.b)), 貨物トリッ プ消費量（式 (13.c c)) によって表される.

続いて目的地, 経路選択はネットワーク均衡条件 を満足するような需要変動型の利用者均衡モデルで ある。なお，本研究では道路ネットワークのみを分 析対象としており，交通機関分担は考慮しない.

まず，利用者均衡配分による経路選択行動の結果 として, 利用されている経路の交通費用は全て等し くなること, そして各リンクと経路の関係から, ゾー ン $i, j$ 間の交通費用は式（24）のようになる.

$$
C_{i j}=C_{i j k}=\sum_{h} \delta_{h, k}^{i j} t_{h}\left(x_{h}\right)
$$

$C_{i j}$ : ゾーン $i, j$ 間の所要時間, $C_{i j k}:$ ゾーン $i, j$ 間の 経路 $k$ の所要時間, $t_{h}:$ リンク $h$ の所要時間, $\delta_{h, k}^{i j}:$ 経 路 $k$ の中にリンク $h$ が含まれれば 1 ，そうでなけれ ば 0 の值を取るダミー変数

リンク交通費用は私的限界費用であり，リンクパ フォーマンス関数である。経路費用はこのリンクパ フォーマンス関数を経路で加算した值である.

$$
t_{h}\left(x_{h}\right)=t_{h 0}\left[1+\varsigma\left(\frac{x_{h}}{C P_{h}}\right)^{\eta}\right]
$$

$t_{h 0}$ : リンク $h$ の自由走行時間, $C P_{h}$ : リンク $h$ の交 通容量, $\zeta, \eta$ : パラメー夕

次に，目的地選択モデルについて説明する。ここ では，利用者の目的地選択行動もロジットモデルで 表現することとする。 トリップ目的 $l$ でゾーン $i$ か らの発生交通量がン゙ーン $j$ を選択する確率は以下の ように表現される。 

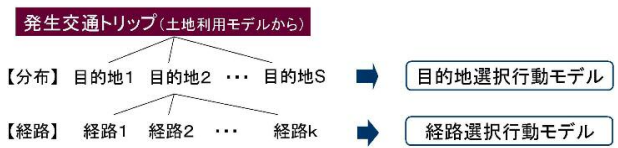

図-3 交通行動モデルの構造

$$
P_{i j}^{l}=\frac{\exp \left[-\theta_{1}^{l} C_{i j}+\theta_{2}^{l} E S_{j}^{l}+\phi_{i j}^{l}\right]}{\sum_{j^{\prime}} \exp \left[-\theta_{1}^{l} C_{i j^{\prime}}+\theta_{2}^{l} E S_{j^{\prime}}^{l}+\phi_{i^{\prime}}^{l}\right]}
$$

$P_{i j}^{l}:$ トリップ目的 $l$ でゾーン $i$ の発生交通量が $j$ ゾーンを選択する確率, $E S_{j}^{l}$ : トリップ目的 $l$ で $j$ ゾーンの経済規模等の固有の説明要因, $\phi_{i j}^{l}:$ キャリ ブレーションで推定される固有のパラメータ

トリップ目的 $l$ で OD ゚ア $i j$ 間の交通量は以下の ようになる。

$$
T_{i j}^{l}=P_{i j}^{l} \cdot Z X_{i}^{l}=\frac{\exp \left[-\theta_{1}^{l} C_{i j}+\theta_{2}^{l} E S_{j}^{l}+\phi_{i j}^{l}\right]}{\sum_{j^{\prime}} \exp \left[-\theta_{1}^{l} C_{i^{\prime}}+\theta_{2}^{l} E S_{j^{\prime}}^{l}+\phi_{i^{\prime}}^{l}\right]} Z X_{i}^{l}
$$

$T_{i j}$ : ODペア $i j$ 間の交通量

\section{（3）従来型と比べた新型 CUEM の特徵}

従来型 CUEM では立地者は土地の上に立地する と想定されていたのに対し，新型 CUEMでは, 開発 者が土地の上に建設する建物床の上に立地すること を想定している，都心部は，郊外部に比べて地価が 高く, 従来型 CUEM では消費する土地面積が都心部 でかなり小さくなる。これに対し，新型 CUEMでは 開発者が都心部に扔いてより多くの建物床を供給す るため, 単位面積当たりでは, 郊外部と都心部で地 価の違いほど賃料は違わず，立地者一人当たりの消 費する建物床面積の割合も土地面積ほど大きくは異 ならない.

その結果，政策・施策・事業の評価においては, 新 型 CUEM は従来型に比べて都心への集積が進んだ 結果を出力すると想像される。しかしながら, 実際 には，CUEMでは交通モデルも含まれており，交通 の混雑の状況によって, 必ずしも上述のような結果 となるとは限らない，立地と交通の相互作用を明示 的に考慮することの意義は，まさにその点にある.

ところで, CUEM は CGE モデルのような長期を 想定した一般均衡体系ではなく，それより短期を想 定した部分均衡体系として構築されているため, 企 業立地者や開発者には利潤が残る。実際，式 (14.b) において，一般均衡モデルのような長期均衡を前提 とした収穫不変 $(a+b=1)$ ではなく収穫聥減 $(0<a+b<1)$ を仮定しており, 建物の生産によって 超過利潤が発生することとなる。要素価格のうち資 材価格 $M$ は固定しており, また，労働投入について は考慮されていない。
土木学会論文集D3 (土木計画学), Vol. 68, No. 4, 333-343, 2012.

この点について CUEM は, 経済均衡モデル体系と して改良の余地が未だ残されている。すなわち，立 地モデルに財の取引市場を導入する必要があり, こ のように空間的な財・サービスの取引を導入するた めには，財・サービスの移動（輸送）を明示的に扱う 必要がある。そのためには, SCGEのようにン゙ーン 間の輸送費を生産者価格に加えた購入者価格の導入 が必要となるが，実際にはそれが非常に困難である ことは，「1。はじめに」に抏いて述べた通りである。

従って, 本研究では超過利潤発生後の分配先や市 場への参入の自由度については, 従来型 CUEM 同様 考慮しないこととする。また，それ故，便益の計測 には，帰着べースではなく，次章で説明するように 発生ベースで計測することとする.

\section{3. 従来型 CUEM と新型 CUEM の比較に用いる データセット}

\section{（1）対象地域と使用するデータ}

モデルの適用対象地域は，図-4に示す通り，山崎 他（2008） ${ }^{12)}$ など同様の関東地方の南部とし, 市区 町村を基礎とした 197 ゾーンを設定する。

本研究で使用した，土地利用と交通に関するデー 夕は表-1に示す通りである。いずれのデー夕も 2005 年時点のものを用いている。建物床面積デー夕 として用いる固定資産課税台帳は全国レベルで整備 されている市区町村単位の集計データであり，2002 年より無償で開示請求が行える。また, 建物賃料 データは不動産情報サービス会社であるアットホー ム（株）の協力を得た同社の物件デー夕（住宅用途： 約 140 万件, 業務用途：約 14 万件）であり，それを 用いてゾーンの代表值（ここでは単純平均）を算出 した，交通は自動車交通のみを対象とし，交通基盤 としては主要道路のみを考慮した。

\section{（2）パラメータの推定}

従来型・新型両 CUEM に打ける効用関数・利潤関 数に直接関わるパラメータの推定結果を表-2に示 す。推定には単一方程式ごとに最小二乗法を用い た：新旧両モデルに共通する交通のトリップに関す るパラメータの值はほとんど変わっていないことが 分かる，交通関連のパラメー夕は千葉県・株式会社 価值総合研究所 (2007) ${ }^{11)}$ と同様である. 目的地選 択モデルのパラメータは吉田・原田 (1996) ${ }^{14)}$, 交通 工学研究会 (1994) ${ }^{15)}$ の方法を用いて推定しており, その結果は表-3に示す通りである。 その他のパラ メータ $\theta, \sigma, \phi$ (添え字略) はキャリブレーション 


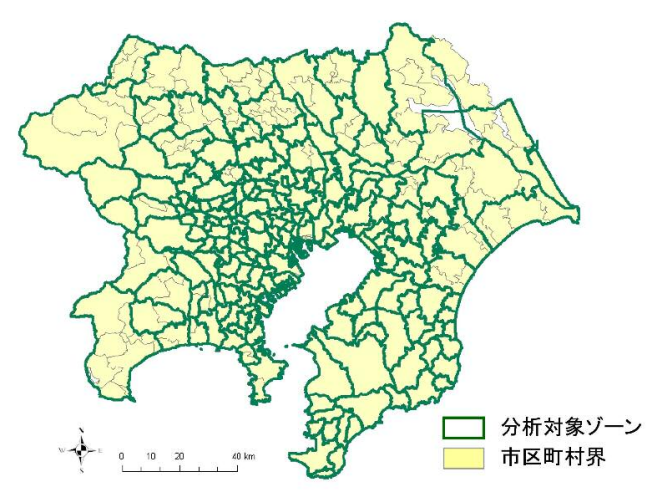

図-4 分析対象地域及びゾーンの設定

表-2 パラメータの推定結果

\begin{tabular}{|c|c|c|c|c|c|}
\hline \multicolumn{3}{|c|}{ (a) 従来型CUEM } & \multicolumn{3}{|c|}{ (b) 新型CUEM } \\
\hline ت゙ータ項目 & パラメータ & t値 & F゙ータ項目 & パラメータ & t t值 \\
\hline 土地消費 $(\alpha \mathrm{a})$ & $1.5 \times 10^{-2}$ & 41.1 & 住宅建物床消費 $(\alpha \mathrm{a})$ & $1.6 \times 10^{-3}$ & 42.1 \\
\hline 私事トリップ $(\alpha x)$ & $9.2 \times 10^{-2}$ & 13.4 & 私事トリップ $(\alpha x)$ & $9.2 \times 10^{-2}$ & 13.4 \\
\hline 土地消費 $(\beta a$ ) & $5.2 \times 10^{-3}$ & 16.9 & 業務建物床消費 $(\beta$ a $)$ & $4.4 \times 10^{-4}$ & 27.4 \\
\hline 業務トリップ $(\beta \mathrm{b})$ & $8.8 \times 10^{-2}$ & 27.0 & 業務卜リップ $(\beta b)$ & $8.8 \times 10^{-2}$ & 27.0 \\
\hline 貨物トリップ $(\beta \mathrm{f})$ & $1.1 \times 10^{-1}$ & 15.9 & 貨物トリップ $(\beta f)$ & $1.1 \times 10^{-1}$ & 15.9 \\
\hline & & & a(住宅) & $6.3 \times 10^{-2}$ & 52.0 \\
\hline & & & b(住宅) & $4.5 \times 10^{-1}$ & 54.9 \\
\hline & & & $a($ 業務 $)$ & $4.2 \times 10^{-2}$ & 54.2 \\
\hline & & & b(業務) & $2.3 \times 10^{-1}$ & 55.6 \\
\hline
\end{tabular}

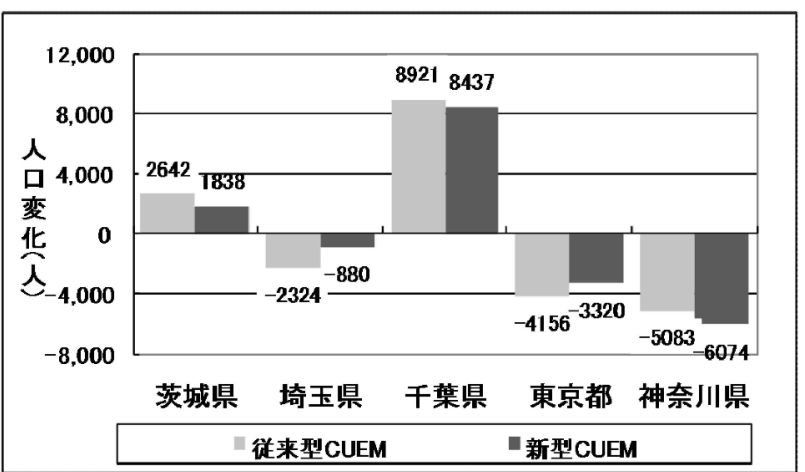

図-5 都県別の人口変化

で算出している。

\section{4. 政策シミュレーションによる従来型 CUEM と新型 CUEM の実証比較}

\section{（1）シミュレーションの概要}

政策シミュレーションの対象とするプロジェクト 東京湾アクアラインの料金值下げとした。具体的に は, 平成 12 年 7 月の料金改定以降の料金である 3, 000 円 (Case1) から半分の 1,500 円 (Case2) への 值下げを想定する。効果の計測方法はモデルのパラ メータ推定に用いたデータの時点（基準年）である 2005 年に扔ける変化 $(\{$ Case 2$\}-\{$ Case 1$\})$ により計測 する.

本稿では, 交通市場に着目し, ゾーンごとの発生
表-1 使用するデータ

\begin{tabular}{|c|c|c|c|}
\hline データ項且 & 単位 & 分類 & 出典 \\
\hline 人口 & 人 & "----- & 国勢調查 \\
\hline 従業者 & 人 & ----- & 国勢調査 \\
\hline 建物床面積 & $\mathrm{m}^{2}$ & 住宅·業務別 & 固定資産課税台帳 \\
\hline 土地面積 & $\mathrm{m}^{2}$ & 住宅·業務別 & 固定資産課税台帳 \\
\hline $\begin{array}{l}\text { 利用可能 } \\
\text { 土地面積 }\end{array}$ & $\mathrm{m}^{2}$ & 住宅·業務別 & $\begin{array}{l}\text { 市街化区域面積 } \\
\text { (都市計画年報) }\end{array}$ \\
\hline 建物賃料 & 円/年· $\mathrm{m}^{2}$ & 住宅·業務別 & 各種民間データ \\
\hline 土地地代 & 円/年· $\mathrm{m}^{2}$ & 住宅-業務別 & 地価公示 \\
\hline \multirow[t]{2}{*}{ 資材価格 } & 円 $/ \mathrm{m}^{2}$ & \multirow[t]{2}{*}{ 住宅·業務別 } & $\begin{array}{l}\text { 建設資材·労働力需要 } \\
\text { 実態調査 }\end{array}$ \\
\hline & 円 $/ \mathrm{m}^{2}$ & & 建物物価ナビ \\
\hline 資材投入量 & 円 $/ \mathrm{m}^{2}$ & 住宅·業務別 & 建築着工統計 \\
\hline 旅客トリップ & 人/年 & $\begin{array}{l}\text { 目的別 (通勤, 通学, } \\
\text { 私事, 業務, 帰宅) }\end{array}$ & 東京都市圏PT調査 \\
\hline 自動車OD & 台/年 & $\begin{array}{l}\text { 乗用車, 小型貨物車, } \\
\text { 普通貨物車 }\end{array}$ & $\begin{array}{l}\text { 道路交通センサス } \\
\text { 自動車起終点調査 }\end{array}$ \\
\hline
\end{tabular}

表-3 目的地選択モデルのパラメータの推定結果

\begin{tabular}{|c|c|c|c|c|c|c|c|c|}
\hline & \multicolumn{2}{|c|}{ 通勤 } & \multicolumn{2}{|c|}{ 私事 } & \multicolumn{2}{|c|}{ 業務 } & \multicolumn{2}{|c|}{ 䝨物 } \\
\hline & バラメータ & t值 & ハヘラ & t值 & バラメータ & t值 & ハiラx-8 & t 值 \\
\hline 交通費用 $\left(\theta_{1}\right)$ & -0.0229 & -41.7 & -0.0176 & -46.7 & -0.0128 & -35.9 & -0.0201 & -67.6 \\
\hline 従業者密度 $\left(\theta_{2}\right)$ & 0.474 & 13.9 & 0.878 & 32.8 & 1.62 & 67.5 & 0.845 & 48.1 \\
\hline 相関係数 & \multicolumn{2}{|c|}{0.604} & \multicolumn{2}{|c|}{0.667} & \multicolumn{2}{|c|}{0.862} & \multicolumn{2}{|c|}{0.674} \\
\hline サンプル数 & \multicolumn{2}{|c|}{5,175} & \multicolumn{2}{|c|}{7,302} & \multicolumn{2}{|c|}{9,523} & \multicolumn{2}{|c|}{19,724} \\
\hline
\end{tabular}

トリップ数と交通費用の施策前後の変化から簡易的 に台形公式（城所（2003）16）を参照）により消費者 余剩（CS）を計測することとした，具体的には，次 式を用いている。

$$
C S=\frac{1}{2} \sum_{i} \sum_{k}\left(\left.Z X_{i}^{k}\right|_{\text {without }}+\left.Z X_{i_{\text {with }}^{k}} q_{q_{i}}\right|_{\text {without }}-q_{i_{\text {with }}}\right)
$$

ここで, $Z X$ は目的 $(k)$ 別ゾーン $(i)$ 別の発生卜 リップ総数, $q$ は前述の一般化費用を表し, また, without：施策無し，with：施策有りである.

（2）シミュレーションの結果

a）立地への影響

図-5に, 従来型 CUEM, 新型 CUEM の二つのモデ ルによる, アクアライン料金值下げによる人口変化 の計算結果の差 (\{Case 2$\}-\{$ Case 1$\}$ ) を都県別に示す. 二つのモデルのシミュレーション結果は概ね同じよ うな傾向となり, 中でも千葉県の人口が大幅に増加 することが特徵的である。，一方で，二つのモデルの 違いに着目すると，埼玉県と東京都において，新型 CUEM の方が人口の減少量が小さいことが分かる. 次に, 各ゾーンの人口変化の分布（図-6, 図-7）と二 つのモデルの出力結果の差の分布（図-8）を示す. 図-8 より, 新型 CUEM の方が, 従来型 CUEM に比 べて東京都心部，埼玉県東部等で人口を多く推計し ていることが分かる。これは，新型 CUEM が建物市 場を考慮していることにより，都心部と郊外部の実 容積率の差が表現できていることによると考えられ る（図-9）。すなわち, 都心部では, 土地面積に比べ て建物床面積の供給可能量が多いため, 新型 CUEM 


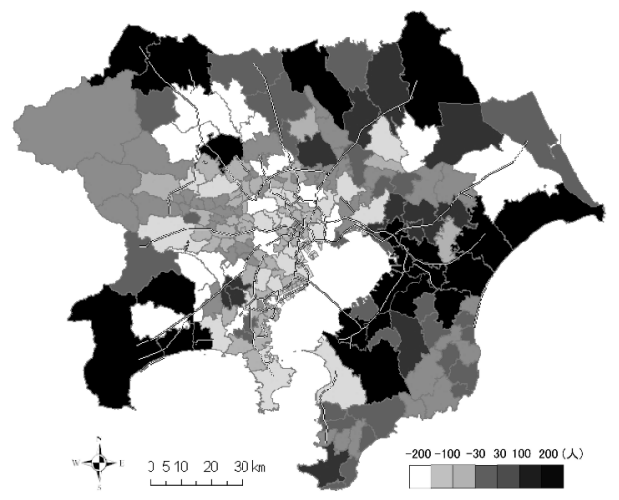

図-6 従来型 CUEM を用いたゾーン別の人口変化

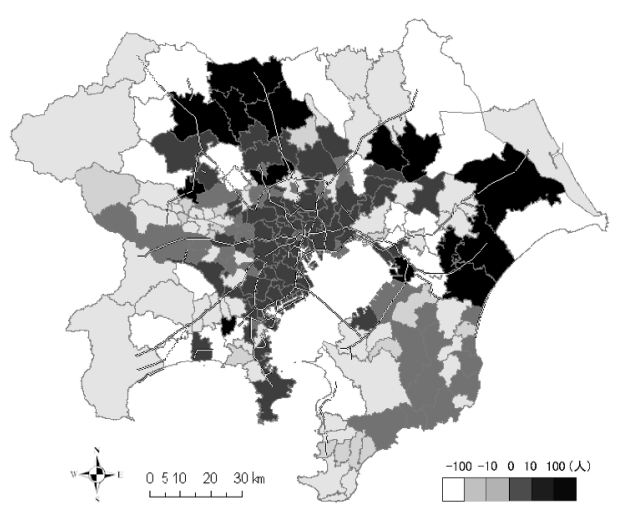

図-8 新型 CUEM と従来型 CUEM の差（ゾーン別の人口 変化)

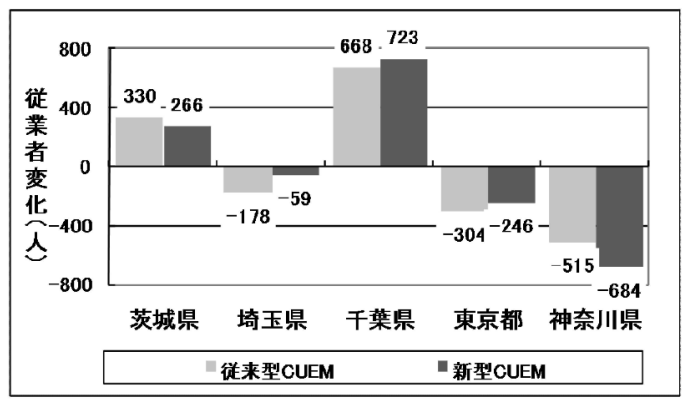

図-10 都県別の従業者変化

では，従来型 CUEM を用いた土地地代をもとに想定 される建物賃料よりも割安な賃料が均衡賃料として 求まり, 立地を促す。

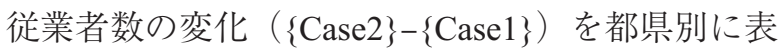
示したものが図-10である.人口の変化と同様に, 二つのモデルのシミュレーション結果は総じて似た ような傾向を示し, 千葉県の従業者数が大幅に増加 することが特徵的である一方で, これも人口の変化

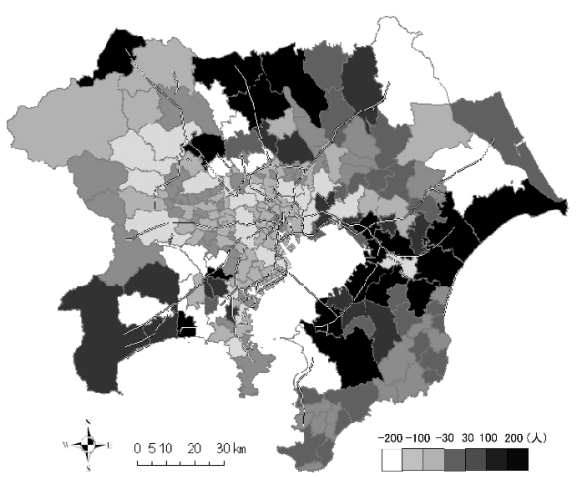

図-7＼cjkstart新型 CUEM を用いたゾーン別の人口変化

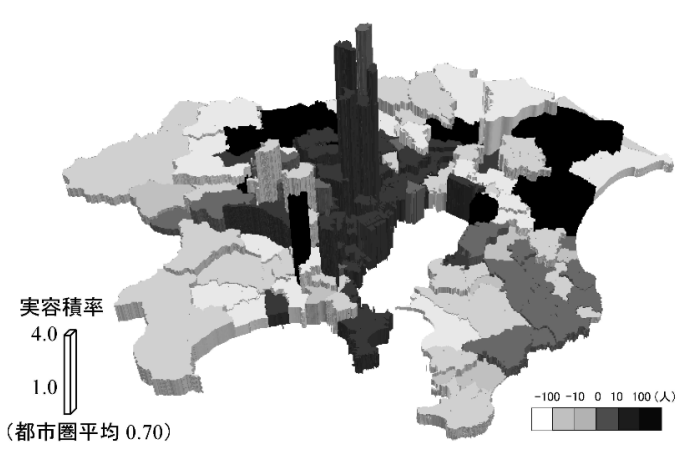

図-9 新型 CUEM と従来型 CUEM の差（ゾーン別の人口 変化）と実容積率

と同様に，新型 CUEM の方が埼玉県・東京都などの 容積率の高い地域で従業者の減少が緩やかである. そもそも従業者数の変化量は人口のそれと比べると 一桁小さく, ゾーンを細かくした場合の誤差等の影 響は人口の場合に比べると相対的に大きくなるとは 考えられるものの, 各ゾーンの人口変化の分布（図 -11, 図-12）と二つのモデルの出力結果の差の分布 (図-13), ゾーン別の従業者変化と実容積率の関係 （図-14）からも，二つのモデルによる従業者数の出 力結果の差の地域的な傾向は, 人口変化の場合とほ ぼ同様の傾向であると判断される。

b）交通への影響

配分交通量の変化を図-15，図-16に示す，二つの モデルの共通の傾向として, 当然ながらアクアライ ンの交通量が増加し, 湾岸部の交通量が減少する。 次に，二つのモデルを用いて算出した配分交通量の 差を図-17に示す。新型 CUEM の方が東名・関越・ 東関東などの高速道路を通る交通量が多く推計され た。これは, 高速道路周辺地域に打ける立地量が新 型 CUEM の方でより多く推計されていることによ るものと考えられる。また，郊外部では配分交通量 


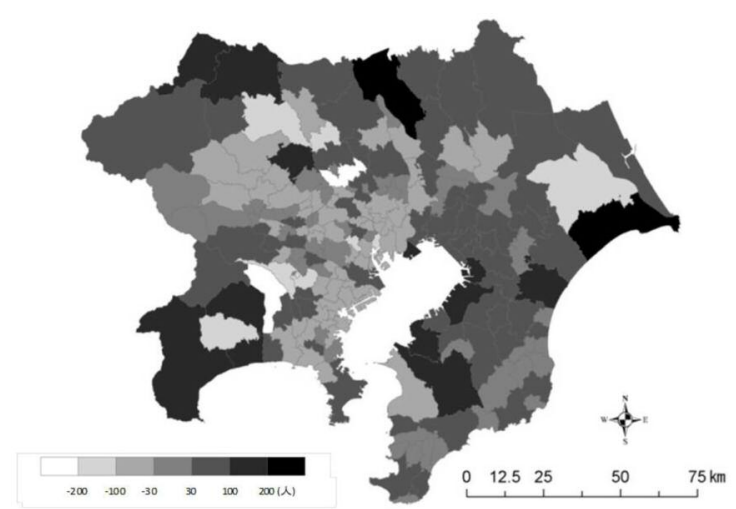

図-11 従来型 CUEM を用いたゾーン別の従業者変化

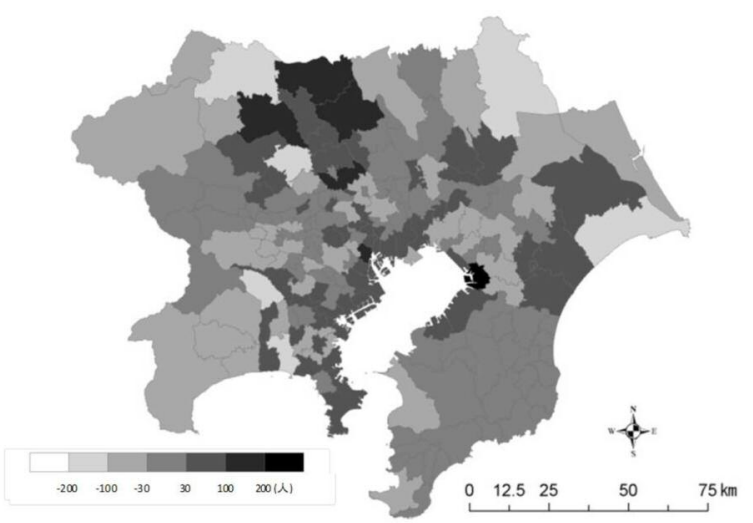

図-13 新型 CUEM と従来型 CUEM の差（ゾーン別の従 業者変化)

が減少している箇所が多い.

続いて, 道路ネットワーク上の基礎評価指標の変 化率を表-4に示す．新型・従来型いずれの二つのモ デルともアクアライン料金值下げによってトリップ 数が微増するものの, 平均トリップ長は減少する. 一方, 二つのモデルの異なる傾向として, 新型 CUEM の方が, 従来型に比べて平均トリップ長が短 い.これは，既述のと打り，新型の方が都心部に拀 ける集積が高く推計されることによるものであると 考えられる。ささらに, 新型 CUEM では都心部に交通 量が集中する結果となり，それに伴う混雑により平 均速度の低下を招いている。

\section{c）便益への影響}

4.（1）で述べたとおり, 発生べースの消費者余剩 法に基づき計測した便益と, アクアラインの交通量 変化に伴う料金収入変化を表-5に示す.

新型・従来型いずれのモデルによる計算において も, 便益が減収額を上回っている。一方で, 新型 CUEM によって推計される便益は従来型の 6 割程度 に留まっている。これは, 上述のと抢り, 都心部・業

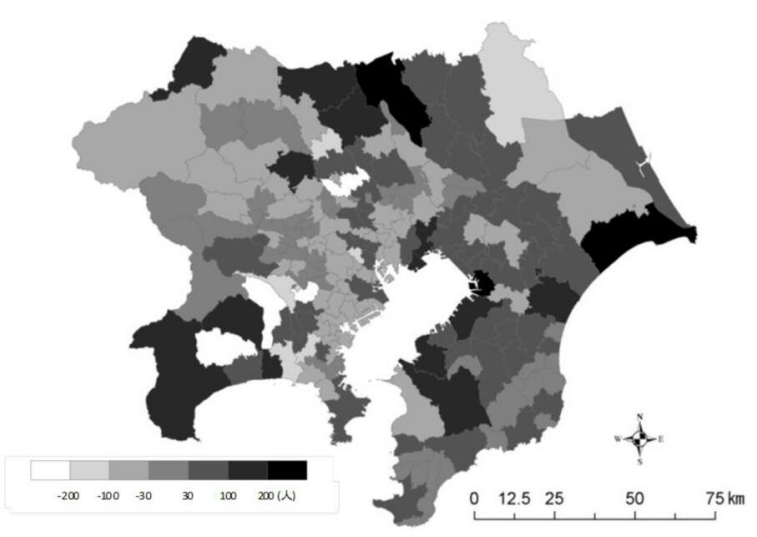

図-12 新型 CUEM を用いたゾーン別の従業者変化

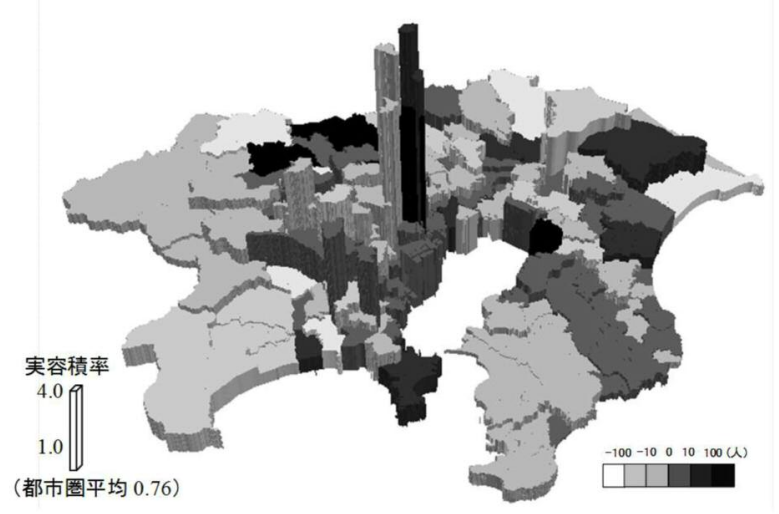

図-14 新型 CUEM と従来型 CUEM の差（ゾーン別の従 業者変化）と実容積率

務各都市での立地量が従来型に比べて多く推計され るなど交通発生量の地域的な分布が異なることと, それに伴う混雑による速度低下の影響によるものと 考えられる。このように，モデル化の相違によって 推計される便益額に相当程度の差異が生じたこと は，本研究において特筆すべき結果である。

また，新型 CUEM の方が高速道路料金収入の減収 額が少なく推計されている。これは, 新型 CUEM が 既述のと打り高速道路の交通量をより多く推計して いることによるものである.

\section{5. おわりに}

本研究では, 建物市場を考慮した応用都市経済モ デル（CUEM）を構築した，従来型 CUEM と建物市 場を考慮した新型 CUEM の二つのモデルを同一の 分析対象で比較可能な形でモデルの構築を行い，東 京湾アクアラインの料金值下げの効果をシミュレー ションした結果の比較を通して, 建物市場の考慮が 


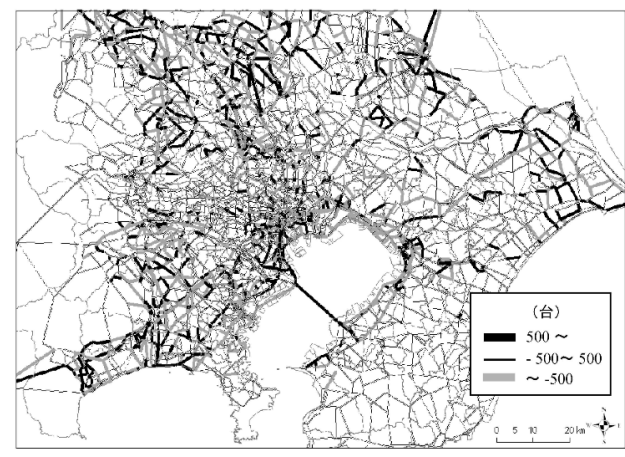

図-15 従来型 CUEM を用いた配分交通量変化

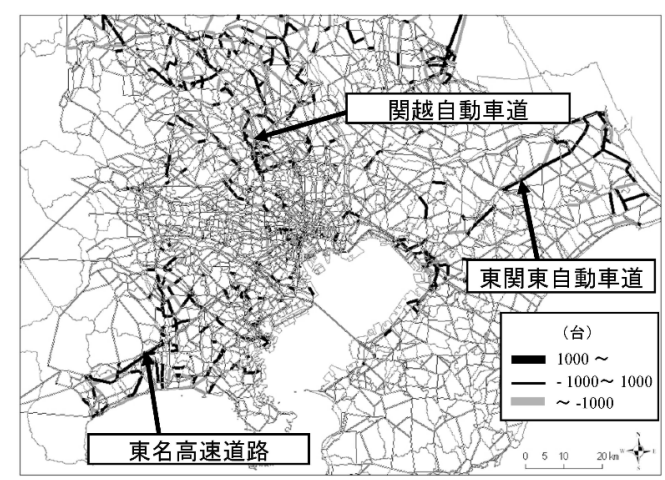

図-17 新型 CUEM と従来型 CUEM の差（配分交通量）

表-5 便益と料金収入

\begin{tabular}{|c|c|c|c|}
\hline 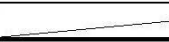 & & 従来型CUEM & 新型CUEM \\
\hline 便益 (1 & /年) & 369.8 & 207.0 \\
\hline & $\begin{array}{c}\text { アクアライン } \\
\text { 料金収入 }\end{array}$ & -23.8 & -21.2 \\
\hline $\begin{array}{c}\text { 料金収人変化 } \\
\text { (億円/年) }\end{array}$ & $\begin{array}{c}\text { 他高速道路 } \\
\text { 料金収 }\end{array}$ & -32.1 & -4.3 \\
\hline & 合計 & -55.9 & -25.5 \\
\hline
\end{tabular}

推計結果に及ぼす影響を実証的に考察した。

その結果，都心部の容積率の高い地域において, 新型 CUEM の方が人口・従業者, 交通量が増加する 傾向が確認された。 これは, 従来型 CUEM に対し, 新型 CUEM では都心部において建物床供給面積が 多くなることにより, 均衡計算で算出される建物賃 料が割安になるためである。その逆に，郊外におい ては, 新型 CUEM の方が人口・従業者, 交通量が減 少する傾向が確認された。しかしながら，都市部へ の集積による交通量の増加は交通混雑を生じるた め, 従来型と新型 CUEM でどの程度結果に差異が生 じるかは，分析の対象とする地域の構造や交通基盤 整備の状況に依存し，一概に述べることはできない。 この点については, 様々な地域やケースを対象とし た実証分析を積み重ねていく必要がある。

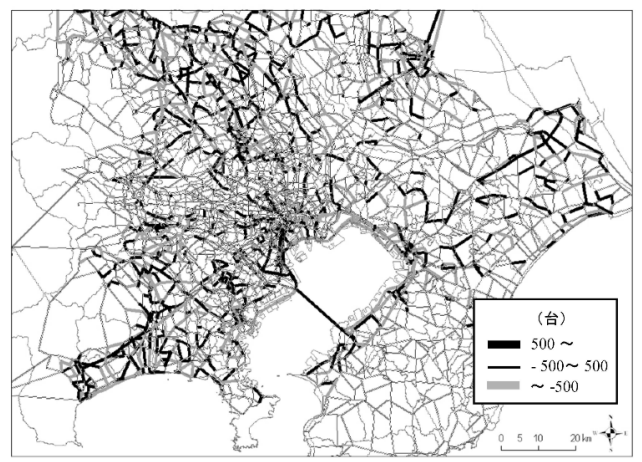

図-16＼cjkstart新型 CUEM を用いた配分交通量変化

表-4＼cjkstart道路ネットワークの評価基礎指標の変化率

\begin{tabular}{|c|c|c|}
\hline & 従来型CUEM & 新型CUEM \\
\hline 自動車総トリップ数 & 0.048 & 0.049 \\
\hline 平均トリップ長 & -0.1 & -0.38 \\
\hline 総走行台キロ & -0.011 & 0.082 \\
\hline 総走行台時 & 0.72 & 0.038 \\
\hline 平均速度 & 0.00 & -0.48 \\
\hline
\end{tabular}

本研究では, 便益額や料金值下げによる料金の減 収額の推計值は, 従来型に比べて新型モデルではそ れぞれ約 6 割, 約 5 割程度と算出されており, CUEMにおいて開発者を考慮することがプロジェク 卜評価に関して無視し得ない影響を及ぼすことが明 らかとなった。すなわち，土地利用変化とそれに伴 う交通量変化に便益が影響されるということが改め て確認され, なるべく現実に近い土地利用/立地変化 を予測することの重要性を再認識する結果となっ た，本研究だけでは，従来型と新型のいずれのモデ ルが予測（forecast）能力の観点で優れているのかは 判断できないが，建物市場をモデル化することによ る土地利用/立地の予測精度の向上が確認できれば, 新型 CUEM の意義はますます大きなものとなる.

謝辞: 本研究は, 筆者らが故上田孝行先生 (元東京大 学教授）から永年受けた指導に負うところが非常に 大きい，研究を遂行する上で，アットホーム株式会 社より不動産物件に関する情報を提供いただいた。 また，匿名の查読者から，論文の根幹に関わる重要 な点について貴重な意見を賜った。ささらに，神戸大 学の小池淳司教授からも，それらに関して多くの有 益な助言を賜った。ここに記してこれらの方々に感 謝の意を表する，無論，本稿に関する有りうべき一 切の誤りは，全て筆者らに属するものである。なお, 
本研究は, 科学研究費助成事業「エクメーネ・リサー ジェンスの新体系構築（研究課題番号：22360202 代表 : 筑波大学 谷口守 教授)」の成果の一部である.

\section{参考文献}

1）上田孝行, 堤盛人, 武藤慎一, 山崎清：わが国におけ る応用都市経済モデルー特徵と発展経緯 -, 応用地域 学会, 11 月 15 日 16 日, 2008, 釧路公立大学. (available：http://www.geocities.jp/arsc2008inkushiro/pap er/B4-2.pdf)

2) Anas, A. and Liu, Y. : A Regional Economy, Land Use and Transportation Model (RELU-TRAN): Formulation, Algorithm Design, and Testing, Journal of Regional Science, Vol. 47, No. 3, pp. 415-455, 2007.

3) Koike, A., Tavasszy, L. and Sato, K. : Spatial Equity Analysis on Expressway Network Development in Japan-Empirical Analysis Using the Spatial Computable General Equilibrium Model RAEM-Light-, Journal of the Transportation Research Board, Vol. 2133, pp. 46-55, 2009.

4) 文世一：交通ネットワークと多都市システムの一般均 衡モデルに関する実証的研究, 平成 $10 \cdot 11 \cdot 12$ 年度科 学研究費補助金 基盤研究(C)(2) 研究成果報告書（課 題番号：10650518).

5) Waddell, P. : UrbanSim: Modeling Urban Development for Land Use, Transportation and Environmental Planning, Journal of the American Planning Association, Vol. 68, No. 3, pp. 297-314, 2002.

6) Ueda, T., Hiratani, K. and Tsutsumi, M. : Landuse Model based on General Equilibrium of Land and Building Markets, Proceedings of International Conference on Land Problem and Urban Policy, pp. 183-198, 1993.

7) 平谷浩三, 中村英夫, 上田孝行, 堤盛人：土地と建物 の多市場同時均衡に基づく土地利用交通モデル，土木 計画学研究·講演集, No. 16, pp. 545-552, 1993.

8）上田孝行：交通改善による生活機会の増大が人口移動 に及ぼす影響のモデル分析, 土木計画学研究・論文集, No. 9, pp. 237-244, 1991.

9) 上田孝行：拡張された立地余剰を用いた一般均衡モデ ル, 土木計画学研究·論文集, No. 10, pp. 183-190, 1992.

10）武藤慎一, 上田孝行, 高木朗義, 富田貴弘：応用都市 経済モデルによる立地変化を考慮した便益評価に関 する研究, 土木計画学研究・論文集, Vol. 17, pp. 257-266, 2000.

11) 千葉県, 株式会社価值総合研究所: 平成 19 年度 県 単道路改良業務委託（東京湾周辺地域の交通・経済等 効果の把握）報告書, 2007.

12）山崎清, 上田孝行, 岩上一騎: 開発人口及び誘発・開 発交通を考慮した東京湾アクアラインの料金值下げ 効果の計測, 高速道路と自動車, 第 51 巻, 第 6 号, pp. 20-32, 2008.

13）宮城俊彦, 小川俊幸 : 共役理論を基礎として交通配分 モデルについて, 土木計画学研究・講演集, No. 7, pp. 301-308, 1985.

14) 吉田朗, 原田昇：確率的形成を考慮した集計型目的地 選択モデルの研究，土木学会論文集，No.618，1999.

15) 交通研究会編：やさしい非集計分析, 社団法人交通工 学研究会, 1994 .

16) 城所幸弘：交通プロジェクトの便益評価－体系と課題 一, 運輸政策研究, Vol. 2, No. 2, pp. 14-27, 2003.

(2011. 2. 22 受付)

\title{
POTENTIAL OF COMPUTABLE URBAN ECONOMIC MODEL FORMALIZING BUILDING MARKET
}

\author{
Morito TSUTSUMI, Takuya MIYAGI and Kiyoshi YAMASAKI
}

Thus far, many types of computable urban economic (CUE) models have been developed and applied in practice. Most CUE models treat buildings and lands as one set, and it is assumed that the aggregate supply of building spaces in any zone is proportional to the aggregate land supply. Moreover, the modeling of building markets can be the basis of the analysis of the emergence of high-rise buildings particularly in city centers. In this study, we have developed a new CUE model that explicitly formalizes the building market and describes the endogenous supply of building spaces by a representative developer for each zone. Further, the results of both the proposed CUE and conventional CUE models are compared, and the potential of a CUE model for explicitly formalizing the building market is discussed. 